\title{
Air Pollution Impact Assessment of Gresik Industrial Area (KIG) Based on Neighborhood Community in Gresik District
}

\author{
Utari Sulistyandari ${ }^{1}$ \\ Faculty of Architecture, Design and Planning, \\ Magister Program \\ Institut Teknologi Sepuluh Nopember \\ Surabaya, Indonesia
}

\author{
Adjie Pamungkas ${ }^{2}$ \\ Faculty of Architecture, Design and Planning, \\ Department of Urban and Regional Planning \\ Institut Teknologi Sepuluh Nopember \\ Surabaya, Indonesia
}

\author{
Eko Budi Santoso ${ }^{3}$ \\ Faculty of Architecture, \\ Design and Planning, Department of Urban and Regional Planning \\ Institut Teknologi Sepuluh Nopember \\ Surabaya, Indonesia
}

\begin{abstract}
Gresik Industrial Area (Kawasan Industri Gresik - KIG) established at 1972, which was marked by the establishment of PT Petrokimia Gresik, as the third oldest industrial area in Indonesia. There are about $\mathbf{3 0}$ factories of chemical fertiliser factory, food and beverage factories, packaging factories and smelter and refinery. The industrial sector is the sector that contributes more than 50\% of the PDRB in Gresik from the whole sector in 2016. Unfortunately, the operational of KIG has adverse impacts to the environment. Based on air monitoring carried out routinely every year, there is an amount of $\mathrm{NO2}, \mathrm{SO}$, dust and particle production, which is excessive according to environmental health standards - thus resulting unpleasant smell due to excessive production of $\mathrm{NO2}$ and Ammonia, dust, smoke, several health problems such as respiratory problems, environmental allergies, and skin health problem. In 2017 the Gresik Health Service recorded 12,245 people affected by Upper Respiratory Tract Infection (ISPA) triggered by industrial activities in Gresik. Therefore in this study, any impact will be evaluated from the industrial estate activities that have been felt by the neighbourhood community. According to the assessment of the local community, the perceived impact is; smoke, unpleasant smell, dust, changing ecosystem, causing disease, interfering with visibility, hot temperature, and reducing air freshness. The sub-districts that feel the most impact are Kebomas and Manyar sub-districts.
\end{abstract}

Keywords- Industrial area; industrial impact; Gresik community; air pollution

\section{INTRODUCTION}

Gresik Regency is one of the core regions (SurabayaSidoarjo and Gresik) of the Gerbang Kerto Susilo which developed as an industrial area. The development of these industrial activities spurred the growth of settlements for industrial sector workers [1]. Some industries in Gresik include Semen Gresik, Petrokimia Gresik, Nippon Paint, Timber / Plywood and Maspion industries, and many other industries.
The purpose of the construction of industrial estates is as follows [2]; controlling spatial use, enhancing environmental development efforts that are environmentally sound, accelerating industrial growth in the region, increasing industrial competitiveness, increasing investment competitiveness and providing location certainty in planning and infrastructure development, which coordinated between sectors. From the objectives of the industrial estate development, it stated that one of the objectives of industrial estate development was to increase the efforts of environmentally sound industrial development. The early era of Gresik industrialisation was in 1953, since then, the industrial area in Gresik has continued to develop [1]. At that time, the industrial area in Gresik did not come into direct contact with settlements because there were not many immigrant communities. Over time, the industrial estate in Gresik is growing rapidly, and the urgency of settlements close to the workplace is getting higher because of the large number of migrants from outside the city who work and eventually settle in Gresik so that settlements grow close to the area industry to date.

In KIG, there are several industries which consist of fish packing and fish processing industries, chemical processing industries, services and others. Pollution arising from industrial activities in the Gresik Industrial Zone is air and noise pollution. In addition to the Gresik Industrial Area along the Tri Dharma road, there is also the PT Petrokimia Gresik Industry, with a factory that extends to the port area. PT. Petrokimia Gresik is a fertiliser producer which has been operating since 1972, in the production of fertiliser there is processing of fertiliser raw materials in the form of chemicals such as urea, za, and ammonia. Factories in the Industrial Estate of PT Petrokimia Gresik consist of three factories with processing chemicals that are different in each of their factories, and in size, the mass is far greater than the industries in KIG. Pollution sourced from PT Petrokimia Gresik in the 
form of air pollution, namely the disposal of ammonia gas, as well as noise pollution due to the use of heavy equipment operating in factory 1 , factory 2 , and factory 3 .

At present, there has been an environmentally sound industry concept, which is called industrial ecology. Industrial ecology is a system that is used to manage the flow of energy or material to obtain high efficiency and produce less pollution [4]. The main purpose of industrial ecology is to advance and implement the concepts of sustainable development, whether globally, regionally, or at the local level, by trying to find between the needs of the present generation and future generations. The urgency of applying industrial ecology is increasing because industrial activities contribute to the occurrence of climate change, scarcity of resources and reduced biodiversity globally, thus requiring the transformation of industrial systems into environmentally friendly [5].

Industrial waste and the increasing number of vehicles in Gresik Regency have caused air pollution to exceed the threshold. Pollution generally occurs evenly in several regions or sub-districts that are close to the industry. The results of the ambient air test at 12 points showed that the highest air pollution in Gresik was caused by dust, which reached an average of $0.26 \mathrm{mg} / \mathrm{m} 3$. Furthermore, based on the results of the ambient air test of 13 pollutants other than dust, chemical contaminants are also fairly high such as carbon monoxide (CO) reaching 20.0ppm and Hydrocarbon (HC) $0.24 \mathrm{ppm}$. The deterioration of environmental problems results in the emergence of social problems between the industry and surrounding communities regarding pollution and health. Health problems, especially concerning exhaust gases from factories located in the Gresik Industrial Estate, have emerged several times.

\section{AIR POLLUTION CHARACTERISTIC}

The problem that often arises due to industrial area activities is the occurrence of environmental degradation around industrial estates, claims and conflicts between industry parties and surrounding industries related to welfare disparities. As well as potential liquid, gas/air pollution, solids due to industrial activities, as well as technical problems related to the limited raw water source process, generation of energy sources and control of industrial waste management that have an impact on the process of industrial sustainability [3]. Various environmental damage originating from activities from industrial estates are water pollution, water pollution, and land pollution [6].

Clean air has oxygen (O2) levels needed for normal physiological processes. About $99 \%$ of the air inhaled is nitrogen gas and oxygen. Other gases inhaled in very small amounts, where the gas included as pollutant gas. In crowded urban areas, pollutant gas comes from vehicle fumes, factory exhaust gases, power plants, cigarette smoke, and so on that are closely related to the activities of human life. The Environmental Protection Agency (EPA) determines the quality standards of $\mathrm{CO}$ content in the air based on the results of epidemiological studies of $\mathrm{CO}$ toxicity. The carbon monoxide concentration must not exceed 9 ppm during eight consecutive hours and must not exceed $20 \mathrm{ppm}$ in 1 hour. Chemicals in the air that harm living things categorised as air pollutants. There are many types of air pollutants, but the important ones are six types, namely:
1. Ozone (O3)
2. Carbon Oxide $(\mathrm{CO}, \mathrm{CO} 2)$
3. Sulfur Oxide (SO2, SO3)
4. Nitrogen Oxide (NO, NO2, N2O)
5. Particle (Dust acids, leads, pesticide, etc.)
6. Odour

Each of these air pollutants classified as primary (e.g. SO2) and secondary air pollutants (e.g. H2SO4). The air pollutant floats in the air for some time depending on its diameter. Very small particles are harmful to life because they can seep into the lungs and are also carriers of toxic substances that cause cancer.

Air pollution also includes noise. Noise is an unwanted sound and can interfere with the health and comfort of the environment expressed in decibels $(\mathrm{dB})$. Noise can also defined as an unwelcome sound, annoying sound or annoying noise. Based on Kepmenaker, noise is an unwanted sound that comes from tools, a production process that can cause health and hearing problems. A source of noise is a source of sound whose presence is thought to interfere with hearing both from movable and immovable sources. Generally, the source of noise can come from industrial activities, trade, construction, power generation equipment, transportation equipment and household activities. In industry, noise sources can classified into three types, namely:

1. Engine; noise caused by engine activity.

2. Vibration; noise due to vibrations caused by friction, impact or imbalance in movement of engine parts. Vibration occurs on gears, flywheel, torque rods, pistons, fans, bearings, and others.

3. Air, gas, and liquid movement; noise due to movement of air, gas, and liquid in industrial work process activities, for example in gas liquefaction pipes, pipe outlets, exhaust gases, jets, flare booms, and others.

Sound pollution is a matter that must taken into account from activities in industrial estates. Sound pollution is a hidden pollutant that will have an impact on damage and cause harm in the long term and permanent nature [7].

\section{RESEARCH METHODS}

There are two steps in this study; the first is the analysis of secondary data obtained from industry players in KIG. Secondary data collected from PT Petrokimia Gresik, Gresik Environmental Agency (DLH), and PT KIG. Secondary data is in the form of air quality measurement points with measurement values of each compound ( $\mathrm{SO} 2, \mathrm{NO} 2, \mathrm{CO}$, Ammonia, etc.) and noise quality. The data is then interpolated to find out which areas exceed the specified environmental health standards. Interpolation is done using the ArcGIS application.

The second step is identification of impacts. Impact identification is done to find out what impacts are felt by the community around KIG and its distribution. This identification is done using a survey with random sampling methods for the people living in three sub-districts that surround KIG (Gresik, Manyar and Kebomas). The number of respondents is 100 people by distributing evenly in each sub- 
district. Survey questionnaire questions are in the form of open questions about the impact of KIG on them, which are then analysed using quantitative analysis content. The answers to the open questions are grouped to become a big theme that concluded in general.

\section{RESULT AND DISCUSSION}

In identifying the conditions of air pollution in KIG, secondary data collected relating to air quality, and noise in KIG. Secondary data collection is then followed by a survey to confirm what impacts are felt by the surrounding community.

\section{A. Air Quality of KIG}

Secondary data collected was sourced from PT Petrokimia Gresik, Gresik Environmental Service Office (Dinas Lingkungan Hidup - DLH), and PT KIG. Because monitoring of air quality must be carried out by industry twice a year. The first semester of monitoring conducted in May, and the second semester of monitoring conducted in October or November. PT Petrokimia Gresik has five air quality monitoring points, the DLH Gresik has five air quality monitoring points, but only two monitoring points approach the study locus, while PT KIG has five air quality monitoring points. So that there are total of 12 monitoring points of air quality around the KIG.

The following is the location of 12 monitoring points around the $\mathrm{KIG}$

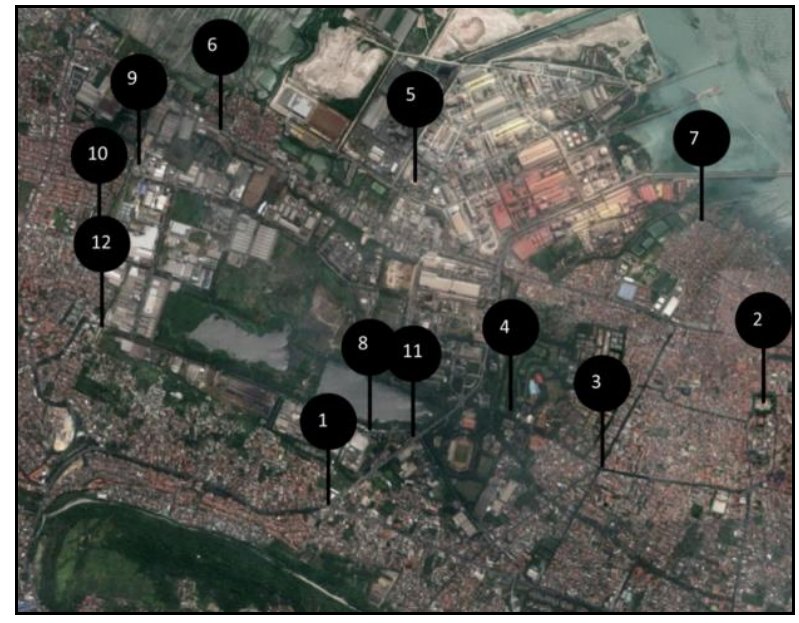

Fig 1 Monitor Points Around KIG

The following are details on the location of the 12 points and their coordinates;

TABLE 1 12-POINT LOCATION AND COORDINATES

\begin{tabular}{|c|c|c|c|}
\hline Point & Monitoring Point & $\mathbf{S}$ & $\mathbf{E}$ \\
\hline 1 & $\begin{array}{c}\text { Tridarma-randuangung T- } \\
\text { Junction }\end{array}$ & $07 \circ 09^{\prime} 46.0^{\prime \prime}$ & $112 \circ 37^{\prime} 54.5^{\prime \prime}$ \\
\hline 2 & Gresik Square & $07 \circ 09^{\prime} 27.6^{\prime \prime}$ & $112 \circ 39^{\prime} 21.3^{\prime \prime}$ \\
\hline 3 & Sukorame Crossroad & $07 \circ 09$ '44.3"' & $112^{\circ} 38^{\prime} 45.9^{\prime \prime}$ \\
\hline 4 & Wisma Kebomas Court & $07 \circ 09 ’ 20.5^{\prime \prime}$ & $112 \circ 38^{\prime} 37.1^{\prime \prime}$ \\
\hline 5 & Petrocentral Frontyard & $07 \circ 08^{\prime} 36.4^{\prime \prime}$ & $112 \circ 37^{\prime} 55.5^{\prime \prime}$ \\
\hline 6 & Jl Raya Sukomulyo & $07 \circ 08^{\prime} 046^{\prime \prime}$ & $112^{\circ} 36^{\prime} 867^{\prime \prime}$ \\
\hline 7 & J1 R.E Martadinata & 07॰09’031'” & $112 \circ 38^{\prime} 673^{\prime \prime}$ \\
\hline 8 & KIG Frontyard Area & 07॰09’32.39”' & $112 \circ 38^{\prime} 09.58^{\prime \prime}$ \\
\hline
\end{tabular}

\begin{tabular}{|c|c|c|c|}
\hline Point & Monitoring Point & S & E \\
\hline 9 & PT Artawa Frontyard Area & $07 \circ 09^{\prime} 12.49^{\prime \prime}$ & $112 \circ 37^{\prime} 12.233^{\prime \prime}$ \\
\hline 10 & $\begin{array}{c}\text { Near Yosowilangon Bridge } \\
\text { Area }\end{array}$ & $07^{\circ} 08^{\prime} 55.03^{\prime \prime}$ & $112^{\circ} 37^{\prime} 06.37^{\prime \prime}$ \\
\hline 11 & $\begin{array}{c}\text { KIG Police Security Post } \\
\text { Area }\end{array}$ & $07 \circ 08^{\prime} 45.40^{\prime \prime}$ & $112^{\circ} 37^{\prime} 32.94^{\prime \prime}$ \\
\hline 12 & IPAL PK KIG Area & $07 \circ 08^{\prime} 38.88^{\prime \prime}$ & $112 \circ 37^{\prime} 39.39^{\prime \prime}$ \\
\hline
\end{tabular}

From the 12 points, the size of the compound measured, then compared with the Ambi Quality Standard for Industry or Other Business Activities which have stipulated in 'East Java Governor Regulation Number 10 of 2009 concerning Ambien Air Quality Standards and Immovable Source Emissions in East Java'. After knowing the measurement values from 2 semesters in 2017 and 2018, the air quality values interpolated in the ArcGIS application. This interpolation was carried out to find out how wide the area around the KIG was affected by the circulation of chemical compounds in the air by industries in the KIG. Besides, interpolation is carried out by referring to quality standards and environmental health. The quality standard and environmental health become an air quality criterion to find out which areas have exceeded the standard. The criteria for air quality are as follows;

\section{TABLE $2 \quad$ AIR QUALITY CRITERIA}

\begin{tabular}{|c|c|c|c|c|c|}
\hline No & $\begin{array}{l}\text { Ambien } \\
\text { t Air } \\
\text { Quality }\end{array}$ & $\begin{array}{l}\text { Quality } \\
\text { Standar } \\
\quad \text { d }\end{array}$ & $\begin{array}{c}\text { Enviro } \\
\text { nment } \\
\text { al } \\
\text { Health } \\
\text { Standa } \\
\text { rd }\end{array}$ & Unit & Value \\
\hline \multirow[t]{2}{*}{1} & \multirow{2}{*}{$\mathrm{SO} 2$} & \multirow{2}{*}{262} & \multirow[t]{2}{*}{80} & \multirow{2}{*}{$\begin{array}{c}\mu \mathrm{g} / \mathrm{Nm} \\
3\end{array}$} & $<80-$ Good \\
\hline & & & & & $\frac{80-262-\mathrm{Bad}}{>262-\text { Very Bad }}$ \\
\hline \multirow[t]{3}{*}{2} & \multirow[t]{3}{*}{$\mathrm{CO}$} & \multirow[t]{3}{*}{22.600} & \multirow[t]{3}{*}{10.000} & \multirow{3}{*}{$\begin{array}{c}\mu \mathrm{g} / \mathrm{Nm} \\
3\end{array}$} & $<10 \mathrm{k}-$ Good \\
\hline & & & & & $10 \mathrm{k}-22.6 \mathrm{k}-\mathrm{Bad}$ \\
\hline & & & & & $>22.6 \mathrm{k}-$ Very Bad \\
\hline \multirow[t]{3}{*}{3} & \multirow[t]{3}{*}{$\mathrm{NO} 2$} & \multirow[t]{3}{*}{92.5} & \multirow[t]{3}{*}{152} & \multirow{3}{*}{$\begin{array}{c}\mu \mathrm{g} / \mathrm{Nm} \\
3\end{array}$} & $<92.5-$ Good \\
\hline & & & & & $92.5-152-\mathrm{Bad}$ \\
\hline & & & & & $>152-$ Very Bad \\
\hline \multirow[t]{3}{*}{4} & \multirow[t]{3}{*}{$\mathrm{O} 3$} & \multirow[t]{3}{*}{200} & \multirow[t]{3}{*}{235} & \multirow{3}{*}{$\begin{array}{c}\mu \mathrm{g} / \mathrm{Nm} \\
3\end{array}$} & $<200-$ Good \\
\hline & & & & & $200-235-\mathrm{Bad}$ \\
\hline & & & & & $>235-$ Very Bad \\
\hline \multirow[t]{3}{*}{5} & \multirow{3}{*}{$\begin{array}{c}\text { Dust, } \\
\text { Particula } \\
\text { te } \\
\end{array}$} & \multirow[t]{3}{*}{260} & \multirow[t]{3}{*}{50} & \multirow{3}{*}{$\begin{array}{c}\mu \mathrm{g} / \mathrm{Nm} \\
3\end{array}$} & $<50-$ Good \\
\hline & & & & & $50-260-\mathrm{Bad}$ \\
\hline & & & & & $>260-$ Very Bad \\
\hline \multirow[t]{3}{*}{6} & \multirow[t]{3}{*}{ Lead, $\mathrm{Pb}$} & \multirow[t]{3}{*}{60} & \multirow[t]{3}{*}{2} & \multirow{3}{*}{$\begin{array}{c}\mu \mathrm{g} / \mathrm{Nm} \\
3\end{array}$} & $<2-$ Good \\
\hline & & & & & $2-60-\mathrm{Bad}$ \\
\hline & & & & & $>60-$ Very Bad \\
\hline \multirow[t]{2}{*}{7} & \multirow[t]{2}{*}{$\mathrm{H} 2 \mathrm{~S}$} & \multirow[t]{2}{*}{42} & \multirow[t]{2}{*}{42} & \multirow{2}{*}{$\begin{array}{c}\mu \mathrm{g} / \mathrm{Nm} \\
3\end{array}$} & $<42-$ Good \\
\hline & & & & & $>42-\mathrm{Bad}$ \\
\hline 8 & Ammoni & 1360 & 1360 & $\mu \mathrm{g} / \mathrm{Nm}$ & $1360-$ Good \\
\hline & $\mathrm{a}, \mathrm{NH} 3$ & & & & $>1360-\mathrm{Bad}$ \\
\hline
\end{tabular}

After the data is interpolated using environmental health standards, it can be seen that some compounds exceed that standard. Interpolation also helps in knowing which area included in the distribution of compounds that exceed environmental health standards. The following are the results of air ambient interpolation carried out with ArcGIS; 


\section{- Dust}

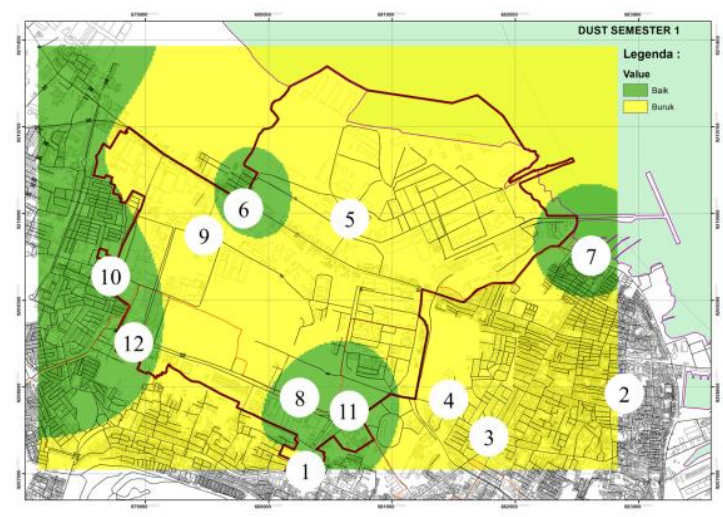

Fig 2 Interpolation of Dust Compounds in Semester 1 (2017) in KIG

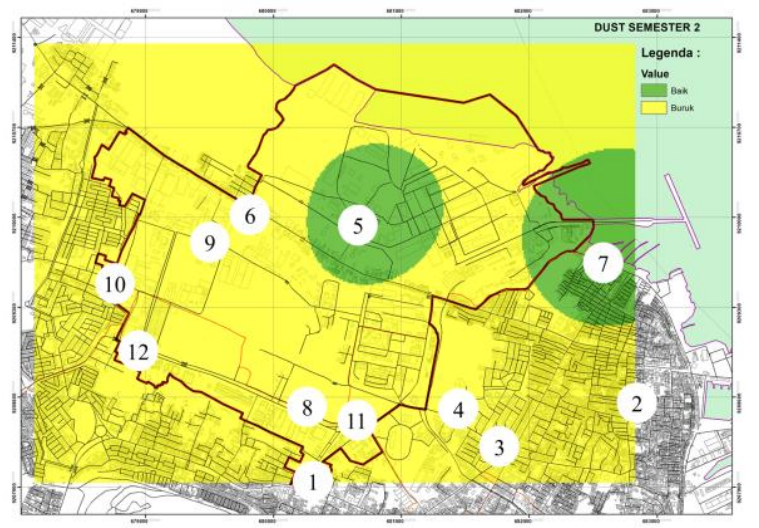

Fig 3 Interpolation of Dust Compounds in Semester 2 (2017) in KIG

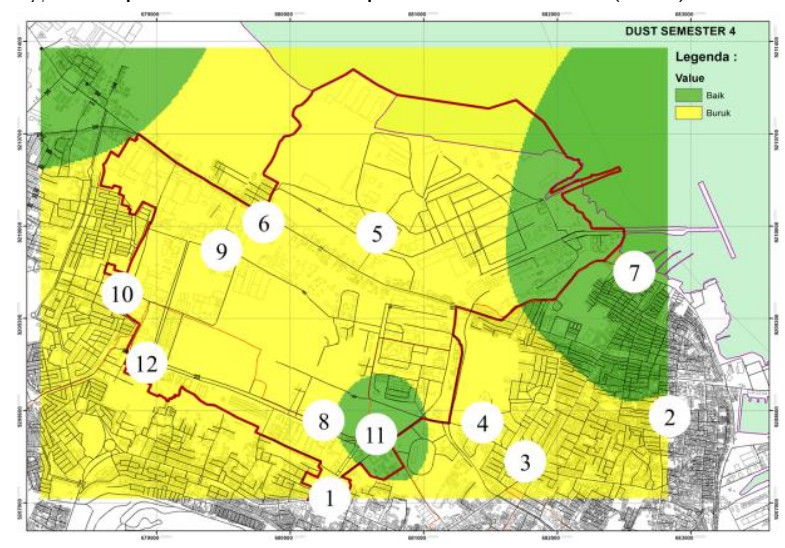

Fig 4 Interpolation of Dust Compounds in Semester 2 (2018) in KIG
- $\mathrm{NO} 2$

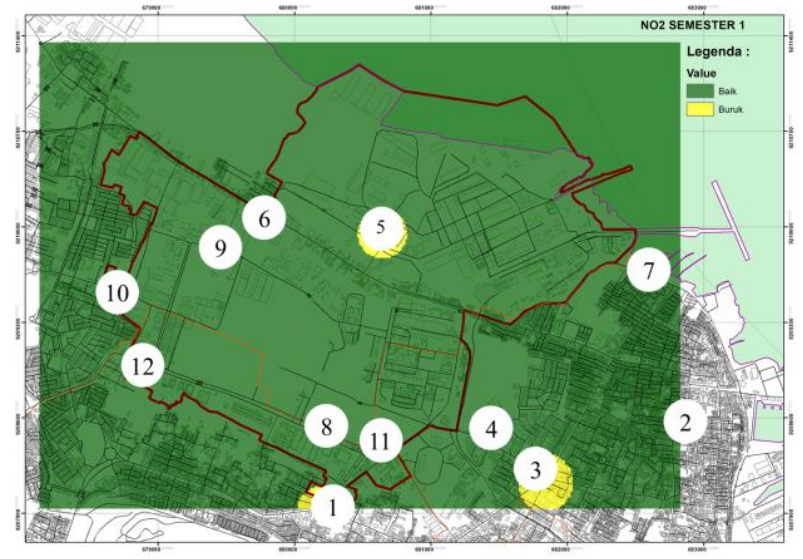

Fig 5 Interpolation of NO2 Semester 1 Compounds (2017) to KIG

- $\mathrm{SO} 2$

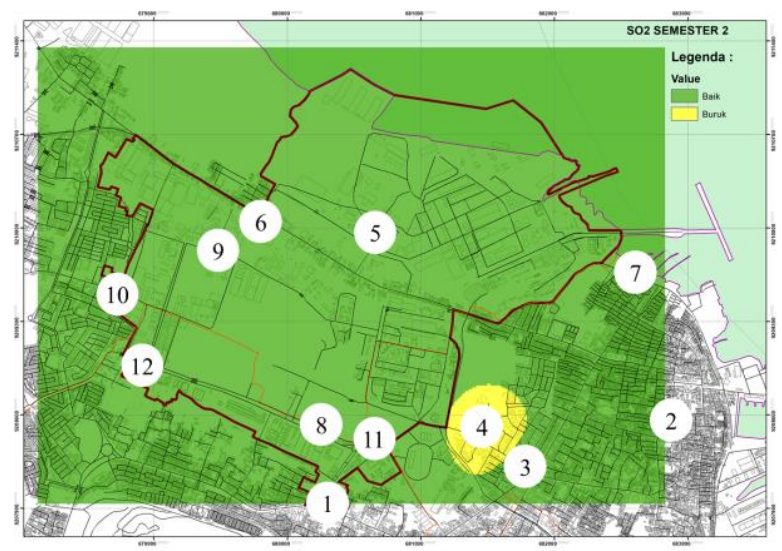

Fig 6 Interpolation of SO2 Semester 2 Compounds (2017) in KIG

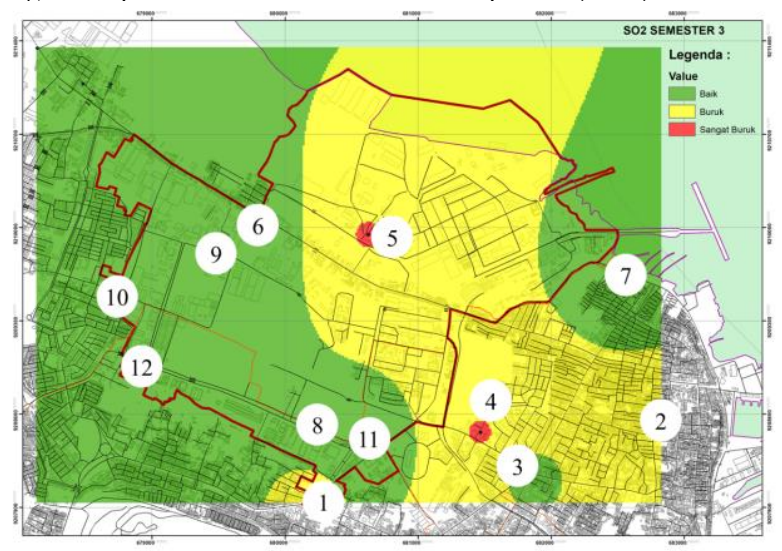

Fig 7 Interpolation of SO2 Semester 1 compounds (2018) in KIG

From the interpolation, it concluded that compounds exceeding environmental health standards distributed around $\mathrm{KIG}$ are $\mathrm{NO} 2, \mathrm{SO} 2$, dust and particles. For dust, the spread is more evenly distributed and reaches the settlement. Whereas for $\mathrm{NO} 2$ and $\mathrm{SO} 2$ the spread is in certain places, specifically in places that have chemical plants and factories with combustion. The spread of NO2 causes unpleasant smell, while SO2 causes smoke. 
Noise quality measurements are carried out together with air ambient measurements. So that the monitoring point used is also the same monitoring point as monitoring air quality. Overall the noise that exceeds the quality standard is at point 6 (Jl Raya Sukomulyo) where heavy-duty vehicle traffic occurs with high intensity. Whereas at point 7 is on Jl. R. E martadinata where the source of noise is PT Petrokimia Gresik, which can be sourced from its industrial activities and trading activities. In the noise interpolation of the Gresik Industrial Estate, the area affected by noise pollution is the Manyar Subdistrict in the west of the KIG and the Gresik District in the east of the industry

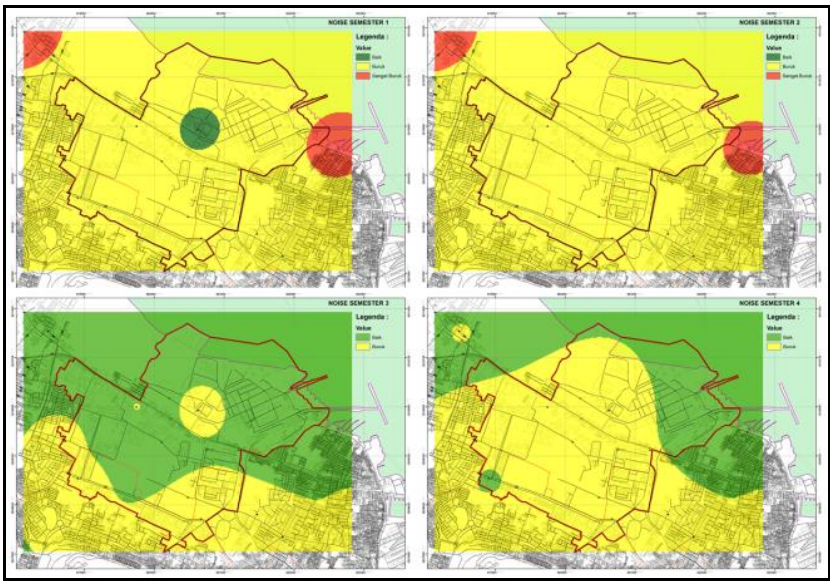

Fig 8

\section{B. Impact of KIG Air Pollution on Surrounding Areas} according to the Neighborhood Community

The identification of the impacts carried out through the survey shows that the spread of the impact of KIG is spread most widely in Manyar and Kebomas sub-districts. This is because the Manyar and Kebomas sub-districts are most closely related to the chemical industry, refineries, management, and the minimum distance between the KIG and the Manyar and Kebomas sub-districts. While the Gresik subdistrict, the impact felt was not too pronounced because of the wide distance between the KIG and the Gresik sub-district. Apart from sufficient distance, there are also urban forests planted with various types of trees.

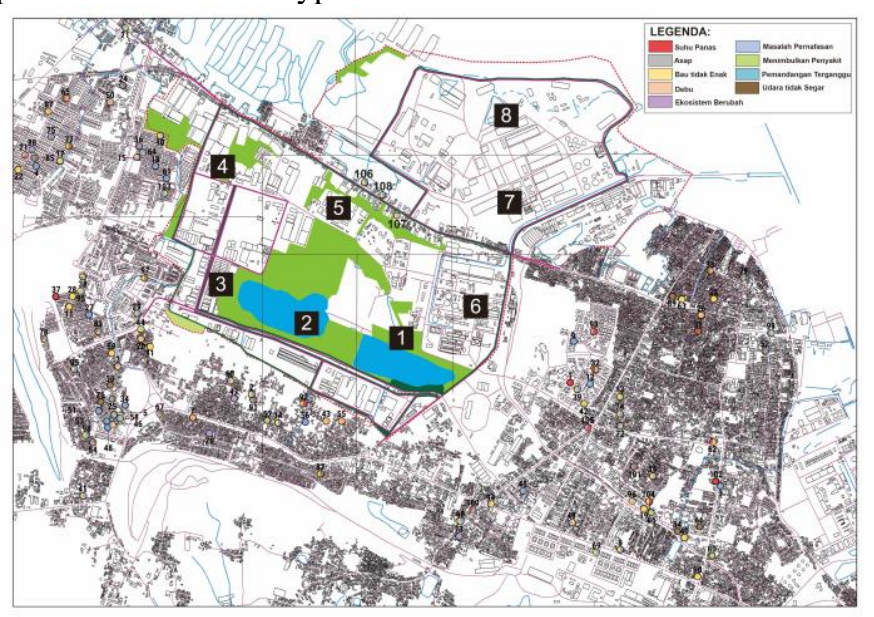

Fig 9 Distribution of Impact of Industrial Area Around KIG
There are nine characteristics of the effects of air pollution from KIG felt by the local community, namely; smoke, unpleasant smell, dust, changing ecosystem, causing disease, interfering with visibility, hot temperature, and reducing air freshness. The following are the impacts that are felt by the community in each sub-district;

TABLE 3

IMPACT CHARACTERISTICS

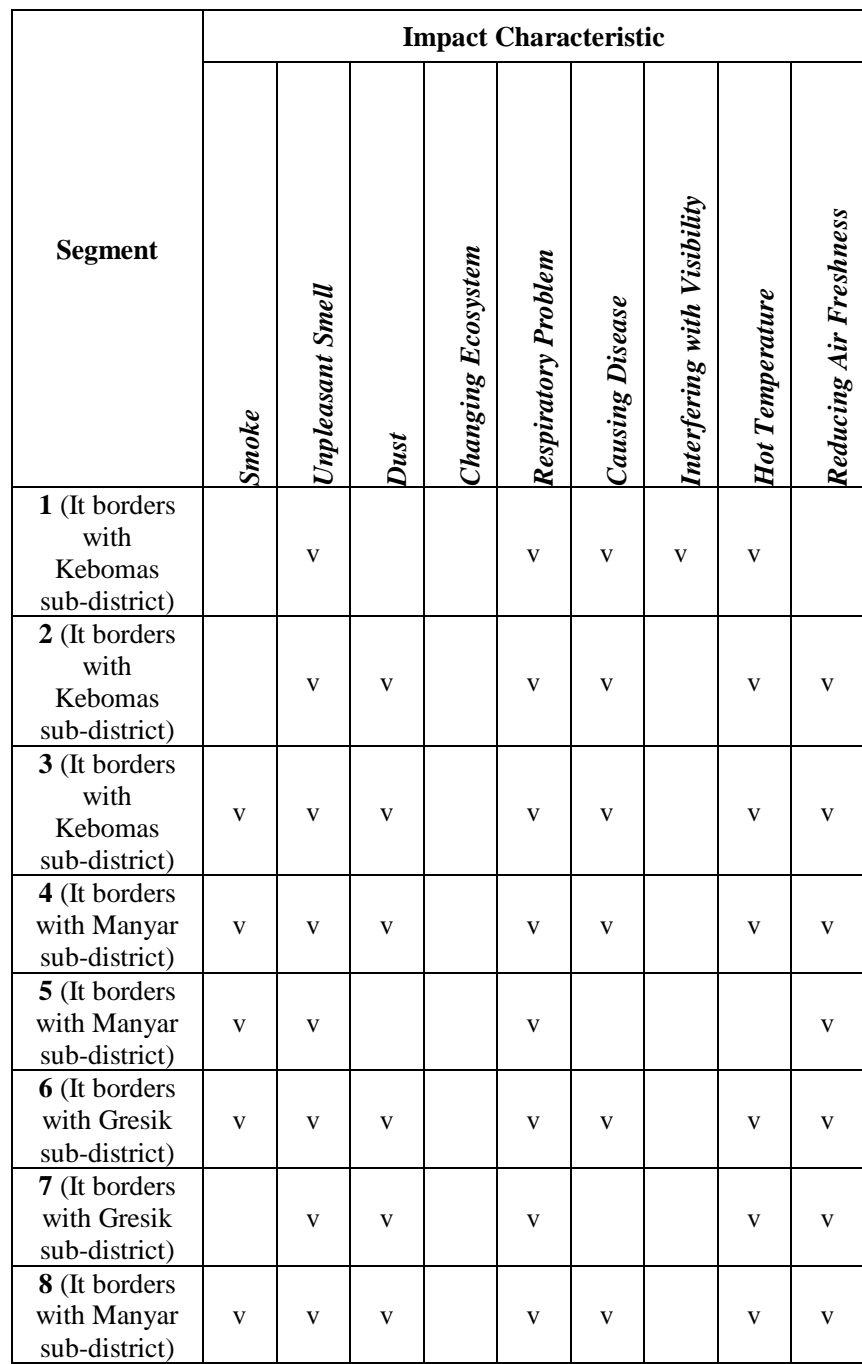

\section{CONCLUSION}

Air-contained compounds in KIG which exceeding the environmental health threshold and quality standards are $\mathrm{SO} 2$, $\mathrm{NO} 2$, and dust particles. The distribution of these compounds results in various impacts on the surrounding area. According to the assessment of the local community, the perceived impact is; smoke, unpleasant smell, dust, changing ecosystem, causing disease, interfering with visibility, hot temperature, and reducing air freshness. The sub-districts that feel the most are Kebomas and Manyar sub-districts. Because of the minimal distance between settlements and KIG it causes air pollution to reach the settlements and causes these impacts. While the Gresik sub-district did not feel the same impact with the other two sub-districts because of the sufficient distance and availability of urban forest. 


\section{REFERENCES}

[1] Pemkab Gresik. 2008. Rancangan RTDR Kecamatan Gresik dan Kebomas Kota Gresik.

[2] Pemkab Gresik. 2009. RAPERDA RTDR Gresik.

[3] Sulaiman. Fatah, Saefuddin. Asep, Syarif. Rizal, Zain. Alinda FM, "Strategi Pengelolaan Kawasan Industri CIlegon Menuju Eco Industrial Park." in Jurnal Perencanaan Wilayah dan Kota, Vol. 19 no. 2, Agustus 2008, hlm 37-57.

[4] Swantomo. Deni, P.C. Maria, and Megasari. Kartini, "Kajian Penerapan Ekologi Industri di Indonesia," in Seminar Nasional III, 2007, Sekolah Tinggi Teknologi Nuklir (STTN).
[5] Anggoro. Suryo, "Eco Desain dan Kontruksi untuk Kawasan EcoIndustrial Park (EIP)," in Jurnal Teknik Lingkungan, Edisi Khusus, 2008, Hal. 33-39.

[6] Rustiati. Ita, "Dampak Industri terhadap Linngkungan dan Sosial,” 2004, unpublished.

[7] Hilmi. Mohd, Kasim. Narimah, and Shafii. Haryati, "Implementation of Buffer Zone in Industrial Area," in IEEE Colloquium on Humanities, Science and engineering, CHUSER, 2014. 